\title{
Pemodelan UML Pada Sistem Pengajuan Dana Anggaran Untuk Peningkatan Produktivitas Perusahaaan
}

\author{
Febri Liantoni ${ }^{1}$, Amalia Yusincha ${ }^{2}$ \\ 1,2,3 teknik Informatika, Fakultas Teknologi Informasi, Institut Teknologi Adhi Tama Surabaya \\ Jalan Arief Rachman Hakim, Klampis Ngasem, Sukolilo, Kota SBY, Jawa Timur 60117 \\ e-mail: ${ }^{1}$ febri.liantoni@gmail.com, ${ }^{2}$ amaliayusincha@gmail.com
}

\begin{abstract}
Abstrak
Dunia teknologi informasi berkembang pesat dengan dukungan teknologi yang semakin canggih. Unified Modeling Languange salah satu sistem yang bisa digunakan untuk standar pembuatan sistem informasi. Dengan menggunakan Unified Modeling Languange perancangan dan pembuatan sistem dapat dikerjakan lebih cepat. Pada penelitian ini pemodelan Unified Modeling Languange digunakan untuk membuat sistem pengajuan dana anggaran. Pembuatan sistem ini bertujuan untuk meningkatkan produktivitas perusahaaan dalam menangani proyek yang dikerjakan. Berdasarkan analisa dan pengujian sistem diperoleh kesimpulan bahwa sistem yang dibuat dapat mempermudah para karyawan perusahaan dalam proses pengajuan dana anggaran dan pertanggungjawaban dana proyek. Sistem yang dibuat juga memberikan informasi mengenai pengajuan dana yang diterima atau ditolak suatu proyek, sehingga dapat membuat pekerjaan yang dikerjakan lebih efisien dan dapat mengurangi resiko kesalahan terhadap pengajuan dana proyek.
\end{abstract}

Kata kunci: Teknologi Informasi, Unified Modeling Languange, Sistem, Dana Anggaran

\begin{abstract}
The world of information technology is growing rapidly with the support of increasingly sophisticated technology. Unified Modeling Language one of the systems that can be used for the standard of making information systems. Using Unified Modeling Language the design and manufacture of the system can be done faster. In this study Unified Modeling Language modeling is used to create a system for submitting budget funds. The creation of this system aims to improve the productivity of companies in handling the projects being worked on. Based on the analysis and testing of the system, it can be concluded that the system created can make it easier for company employees in the process of submitting budget funds and accountability for project funds. The system created also provides information about the submission of funds received or rejected by a project, so as to make the work done more efficiently and can reduce the risk of errors in the submission of project funds.
\end{abstract}

Keywords: Information Technology, Unified Modeling Languages, Systems, Budget Funds

\section{Pendahuluan}

Pada saat ini, dunia informasi berkembang begitu pesat karena ditunjang dengan perkembangan teknologi hingga menjadi semakin canggih. Komputer merupakan salah satu alat yang berguna untuk menunjang perkembangan teknologi informasi. Komputer dapat membantu mengelola sistem informasi hingga mempermudah suatu lembaga untuk mengelola data informasinya. Sistem informasi merupakan alat pendukung utama atas berjalannya suatu perusahaan [1]. Salah satu untuk mengembangkan sebuah sistem informasi dengan menggunakan pemodelan Unified Modeling Languange (UML). UML merupakan sistem yang 
standar dalam industri untuk visualisasi, merancang dan mendokumentasikan sistem informasi [2], [3]. Konsep perancangan menggunakan metode object oriented dengan menggunakan UML, yang terdiri dari: Use Case Diagram, Activity Diagram dan Sequence Diagram [4]-[6].

CV.DMK adalah perusahaan yang bergerak dibidang pengadaan Forklift. Perusahaan ini menangani berbagai kontrak dan kerjasama dengan perusahaan maupun usaha lain dalam General Contractor, Consultant dan Supplier, dan biasa disebut dengan jasa kontraktor. Dalam proses bisnisnya setiap kontrak kerjasama proyek kontraktor dibutuhkan suatu anggaran keuangan, hal ini digunakan dalam membeli material proyek maupun jasa agar proyek dapat diselesaikan dengan baik. Jumlah dana yang dikeluarkan untuk membeli material dan jasa yang tercantum dalam anggaran keuangan dapat diajukan dengan menggunakan Dana Anggaran (DA). Dan hasil realisasi pembelian material dan jasa harus diajukan dengan menggunakan pertangungjawaban proyek.

Manajemen proyek merupakan strategi yang perlu dilakukan dalam mencapai efisiensi dan efektifitas suatu perusahaan [7]. Selama ini karyawan mengajukan Dana Aanggaran dan Pertanggungjawaban proyek masih menggunakan sistem secara manual, yaitu belum adanya sistem aplikasi online dalam mengajukan Dana Anggaran dan Pertanggungjawaban. Data form pengajuan Dana Anggaran dan Pertanggungjawaban tidak terorganisir dengan baik sehingga kesulitan dalam mencari data Dana Anggaran dan Pertanggungjawaban yang sudah diajukan sebelumnya. Selain itu informasi tentang proses pengajuan Dana Anggaran dan Pertanggungjawaban berupa persetujuan dan transfer dari pihak divisi keuangan masih manual, sehingga informasi sering kali tidak tersampaikan dan menyebabkan terhambatnya pekerjaan proyek.

Berdasarkan uraian diatas untuk memberikan informasi proses pengajuan dan kemudahan dalam mengajukan Dana Anggaran dan Pertanggungjawaban, maka dibutuhkan sebuah sistem aplikasi pengajuan Dana Anggaran dan Pertanggungjawaban secara online berbasis web. Sistem yang dibangun dengan menerapkan pemodelan UML.

\section{Metode Penelitian}

Tahapan penelitian yang dilakukan seperti ditunjukkan pada Gambar 1 berikut ini.

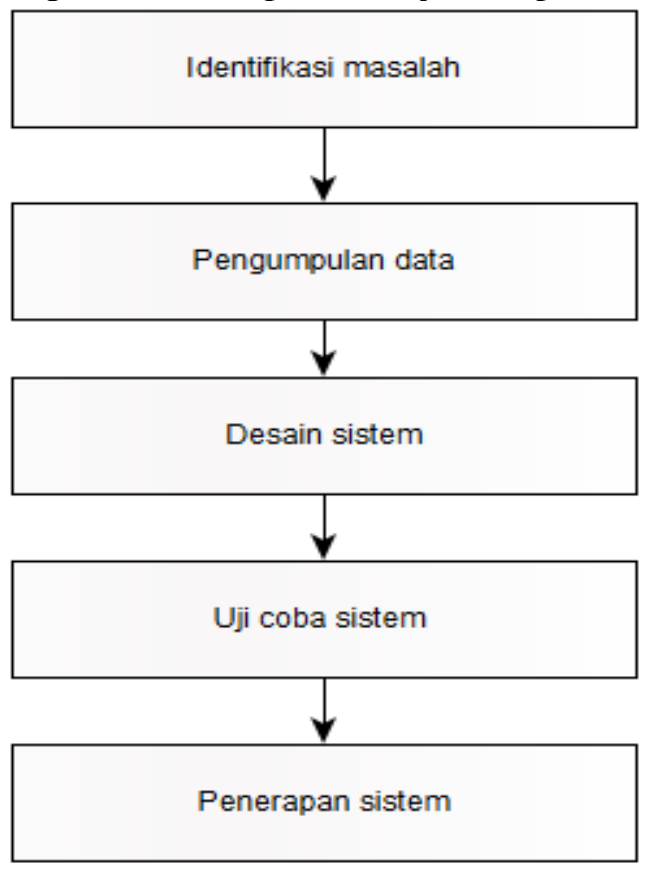

Gambar 1. Tahapan penelitian 
Tahapan yang digunakan dalam penelitian ini terdiri dari identifikasi masalah, pengumpulan data, desain sistem, uji coba sistem dan hasil desain sistem informasi Dana Anggaran dan Pertanggungjawaban. Beberapa langkah untuk menyelesaikan masalah dalam penelitian ini yaitu sebagai berikut, menganalisis sistem, perancangan sistem dan objek, perancangan mengimplementasikan sistem data, perancangan manajemen sistem. Penelitian ini dilakukan dengan menerapkan pemodelan UML untuk membuat sistem informasi Dana Anggaran dan Pertanggungjawaban.

\section{Hasil dan Pembahasan}

Pada pengujian yang dilakukan dengan penerapan pemodelan UML terdapat beberapa langkah. Pemodelan UML yang dilakukan antara lain dengan membuat Use Case Diagram, Activity Diagram, Sequence Diagram dan Class Diagram.

\subsection{Menganalisis Sistem}

Menganalisis sistem adalah langkah awal untuk membuat suatu sistem baru. Dalam langkah ini harus dilakukan analisis terhadap permasalahan yang ada dalam perusahaan. Pada pembuatan sistem kita bisa mengilustrasikan denang menggunakan use case. Use case dideskripsikan secara tekstual dalam bentuk use case scenario untuk menjelaskan interaksi yang terjadi antara aktor dengan sistem [8]. Selanjutnya, use case diilustrasikan secara visual dalam bentuk use case diagram untuk menggambarkan konteks dari sistem yang dikembangkan. Proses menganalisis sistem yang berupa use case diagram ditunjukkan pada Gambar 2.

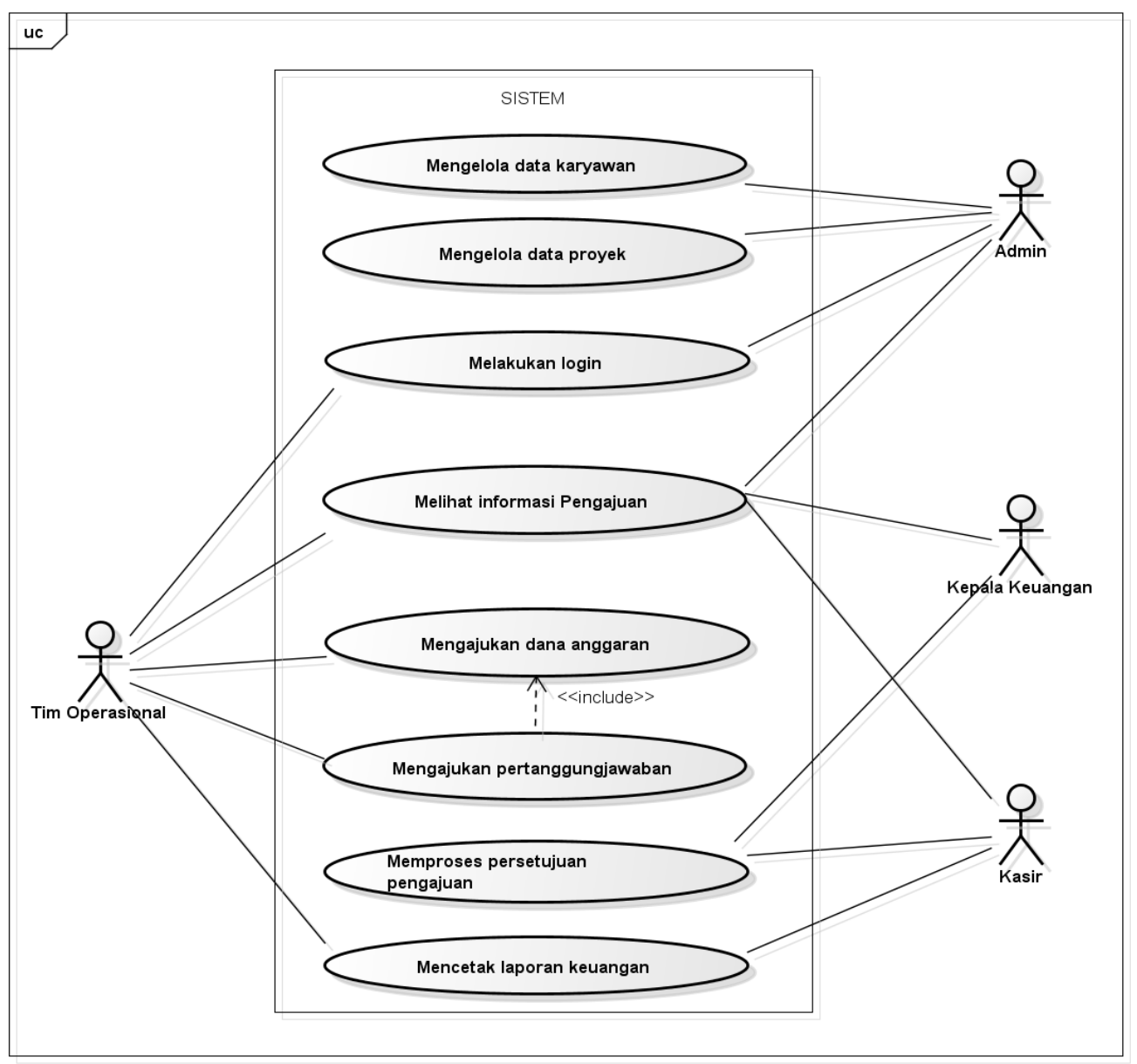

Gambar 2. Use Case Diagram 
Pada Gambar 2 terdapat user Tim Operasional yang haru melakukan login terlebih dahulu sebelum melakukan pengajuan dana anggaran dan mengirimkan pengajuan pada Admin. Dimana Admin dapat memonitoring seluruh kegiatan pengajuan. Selanjutnya Tim Operasional bisa mengajukan pertanggungjawaban tetapi sebelum mengajukan pertanggungjawaban Tim Operasional diharuskan mengetahui pengajuan dana anggaran pada proyek yang sama sebelumnya. Sedangkan Kepala Keuangan dapat melihat informasi pengajuan terlebih dahulu lalu dapat melakukan proses persetujuan pengajuan. Pada use case diatas diatas juga disebutkan bahwa kasir dapat melihat informasi pengajuan, juga memproses pengajuan yang sudah selesai yang selanjutnya bisa dilihat informasinya oleh Tim operasional. Pada use case diatas juga Tim Operasional menerima informasi ketidaksetujuan langsung dari kepala keuangan.

\subsection{Perancangan Sistem Dan Objek (Activity Diagram)}

Activity diagram menggambarkan proses - proses yang terjadi mulai aaktifitas dimulai sampai aktivitas berhenti. Activity diagram juga dapat menggambarkan proses paralel yang mungkin terjadi pada beberapa eksekusi [9]. Menggambarkan berbagai alur aktivitas dalam sistem yang sedang dirancang. Berikut adalah beberapa activity diagram dalam pembuatan aplikasi dana anggaran.

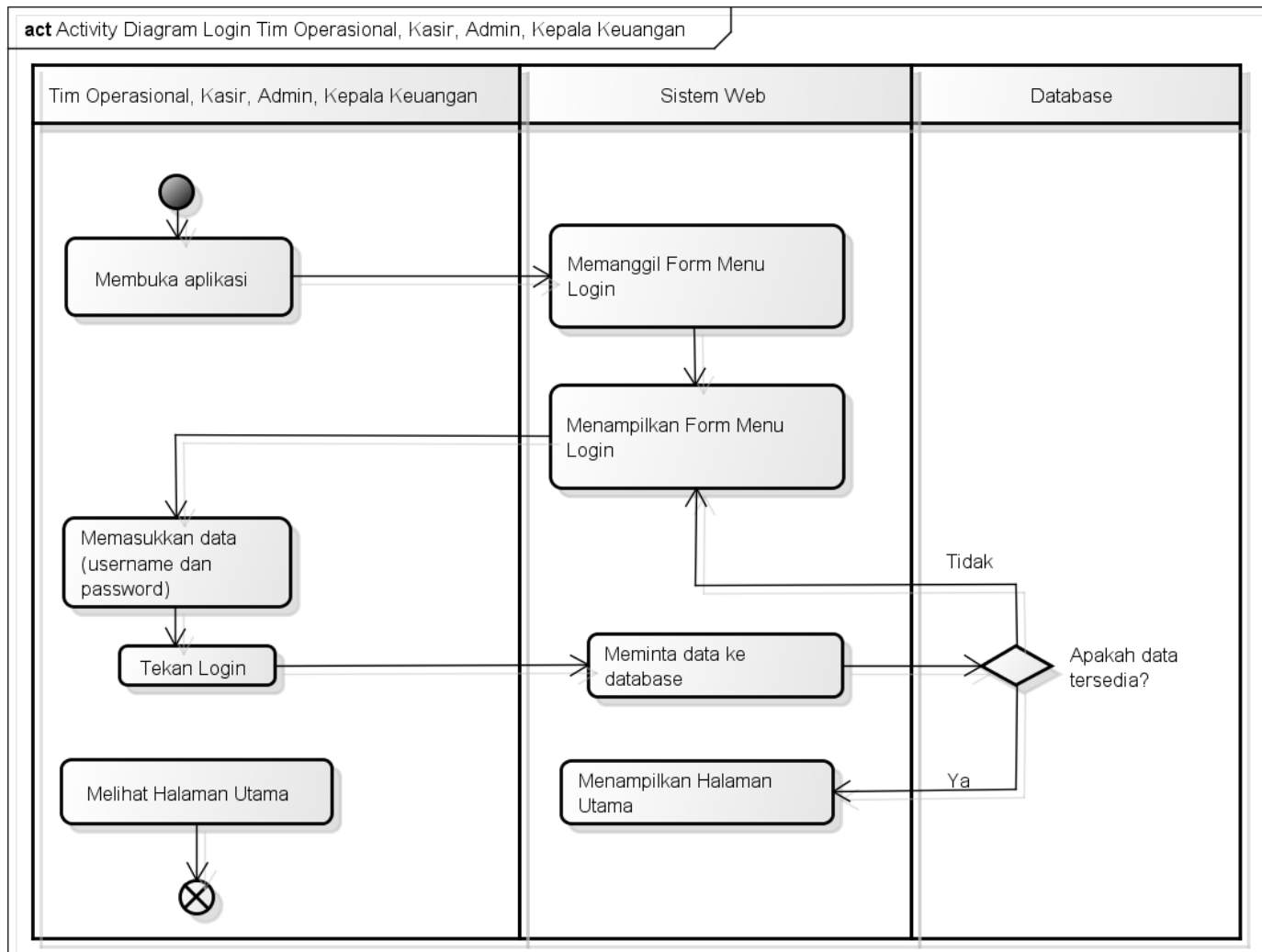

Gambar 3. Activity Diagram Login Karyawan 


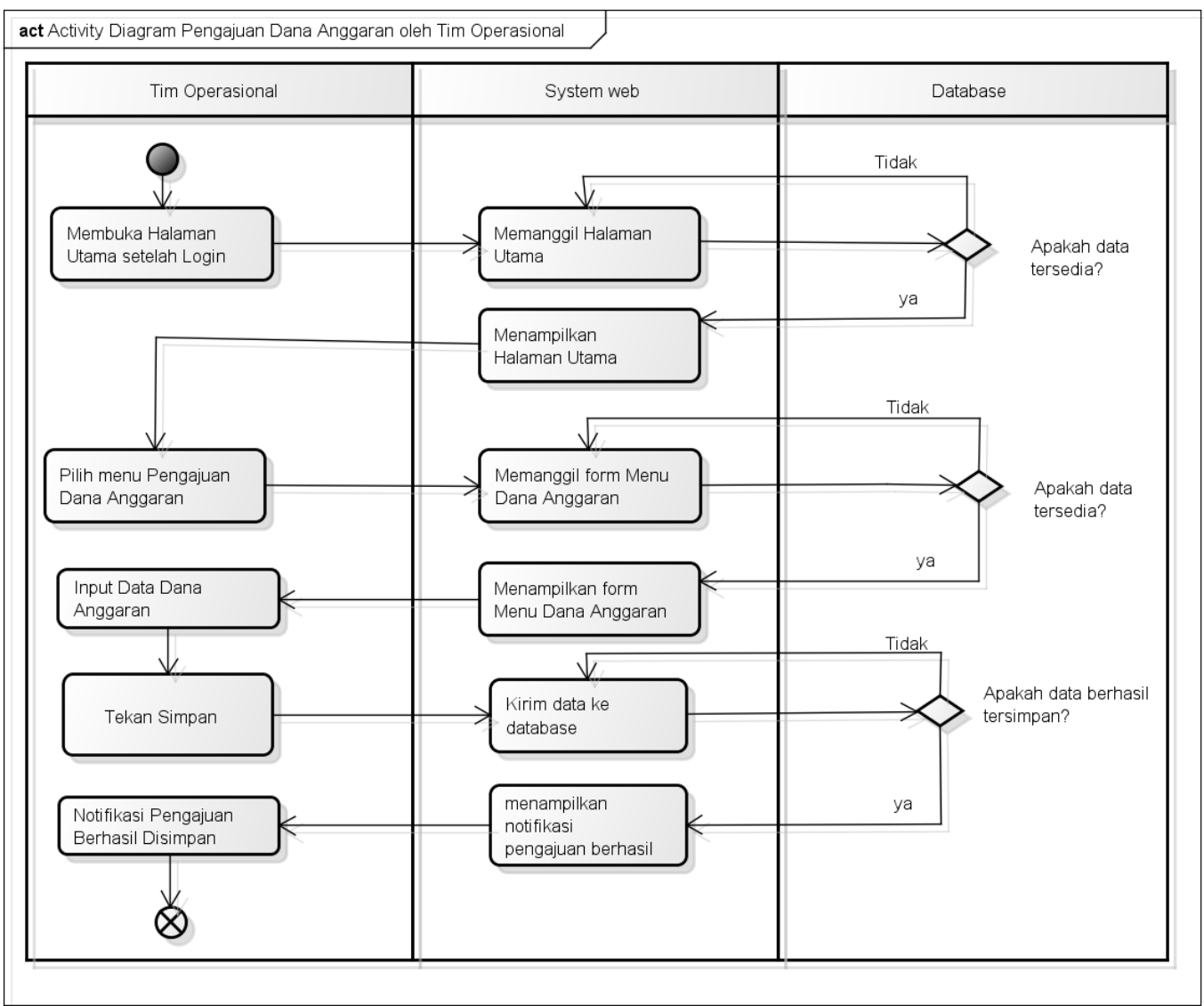

Gambar 4. Activity Diagram Pengajuan Dana Anggaran

Gambar 3 menjelaskan tentang alur aktivitas yang terjadi pada saat karyawan melakukan login. Dimana karyawan ini juga termasuk Tim Operasional, Admin, Kepala Keuangan, dan kasir. Karyawan akan melakukan eksekusi pertama kali setelah web dibuka dan sistem akan memberikan tampilan form login. Dari tampilan form login karyawan diminta untuk memasukkan username dan password untuk dicocokkan dengan database. Jika data tersedia maka akan menampilkan halaman utama (Ya) tapi jika tidak maka akan menampilkan pesan salah (Tidak). Saat menampilkan proses salah maka akan kembali ke menu login dan meminta mengulang ke proses input username dan password, jika benar maka proses selesai.

Gambar 4 merupakan activity diagram pengajuan dana anggaran yang menjelaskan, bahwa tim operasional memilih menu dana anggaran yang ada pada tampilan web dan server akan mengirim database data proyek. Saat tim operasional memilih menu dana anggaran akan muncul tampilan dari form dana anggaran. Setelah itu tim operasional akan menambahkan data dana anggaran proyek yang diinginkan setelah itu tekan simpan data. 


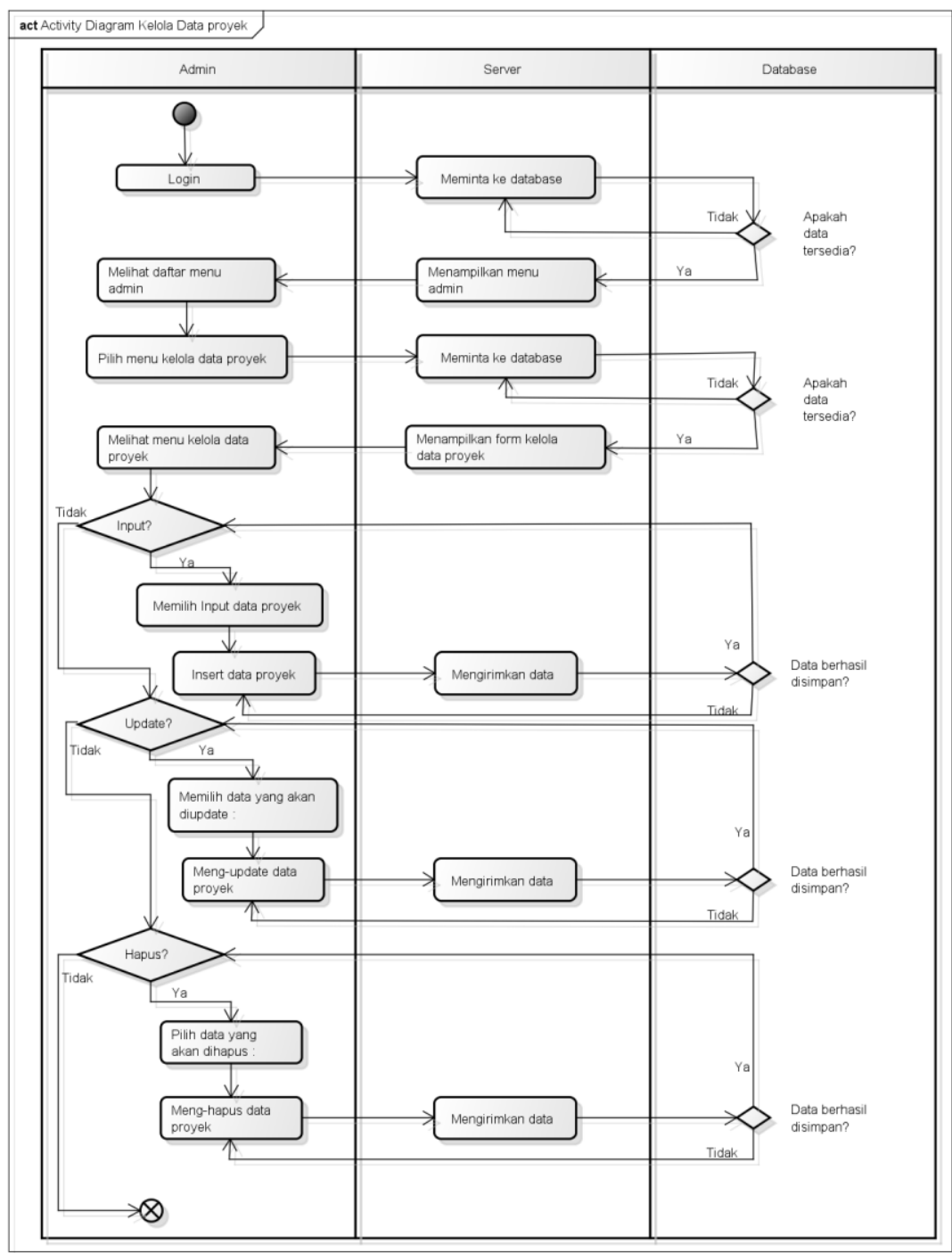

Gambar 5. Activity Diagram Kelola Data Proyek

Gambar 5 adalah activity diagram kelola data proyek yang menjelaskan, bahwa data proyek ini akan digunakan untuk menentukan acuan pengajuan dana anggaran dan pertanggungjawaban karyawan. Terdapat juga fungsi create, update, dan delete pada tampilannya.

\subsection{Perancangan Mengimplementasikan Sistem Basis Data}

Berdasarkan analisis dari Activity Diagram, maka dibuatlah sequence diagram untuk perancangan alur pemrograman di dalam class nantinya. Pada penerapannya, konsistensi desain sequence diagram yang diimplementasi sering menjadi masalah dalam pembangunan perangkat lunak [10]. Beberapa sequence diagram serta class diagram yang dihasilkannya adalah sebagai berikut: 


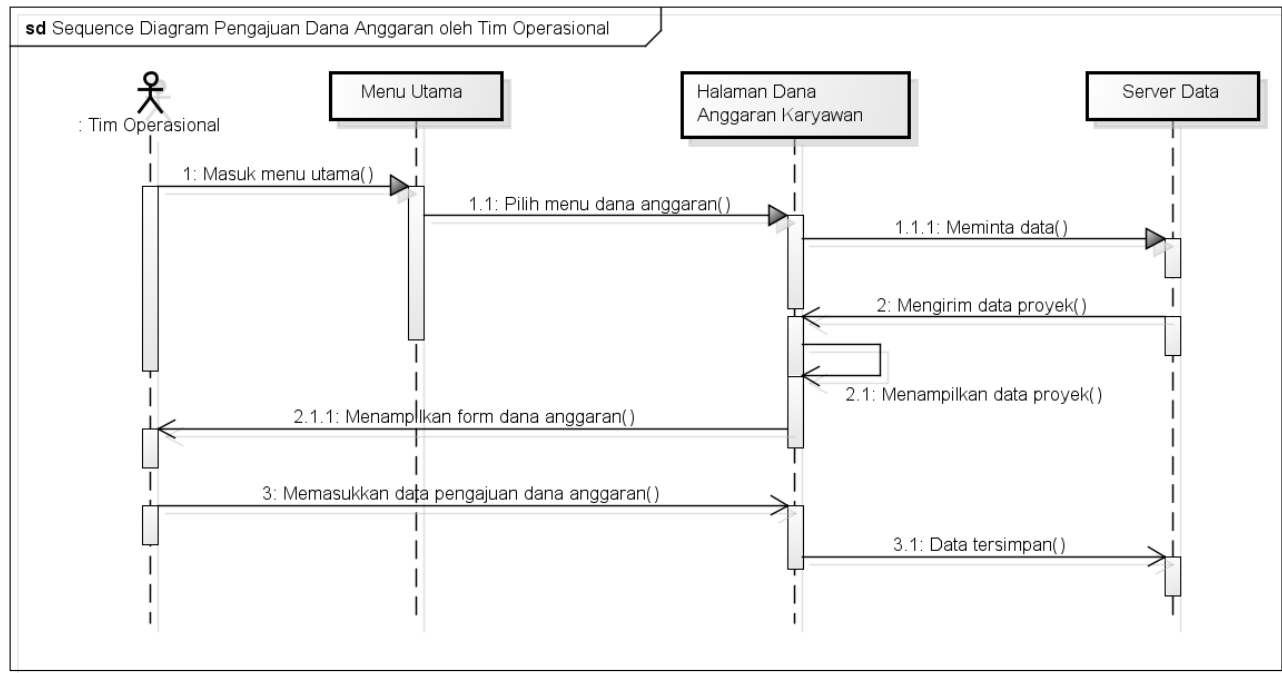

Gambar 6. Sequence Diagram Pengajuan Dana Anggaran

Gambar 6 merupakan sequence diagram untuk mengajukan Dana Anggaran proyek pada tim operasional. Pada halaman dana anggaran tim operasional akan menampilkan data proyek yang akan di isi data pengajuan dana anggaran kemudian data akan tersimpan pada server data.

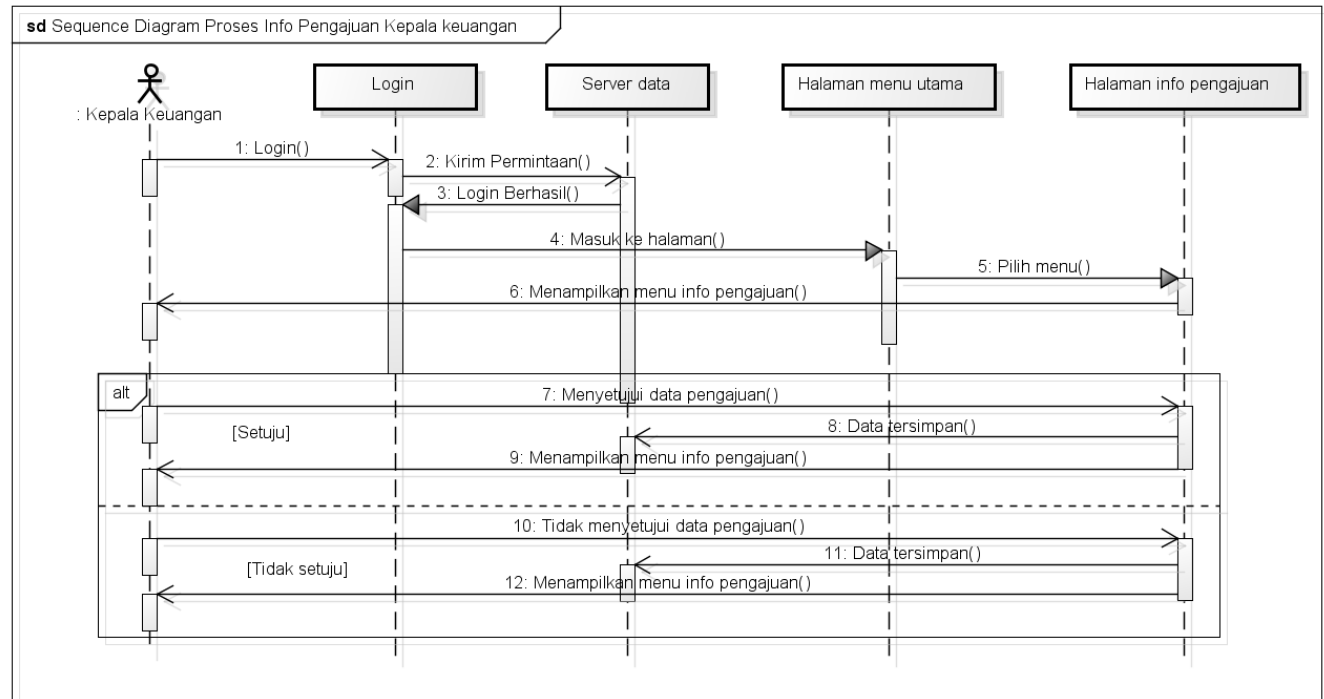

\section{Gambar 7. Sequence Diagram Persetujuan Pengajuan Dana Anggaran oleh Kepala Keuangan}

Pada Gambar 7 menjelaskan sequence diagram proses informasi pengajuan oleh kepala keuangan, dimana kepala keuangan melihat tampilan menu proses pengajuan. Setelah tampilan pengajuan bisa dilihat, kepala keuangan bisa memilih proses pengajuan. Jika pengajuan di setujui maka pengajuan akan dilanjutkan. Namun jika pengajuan tidak disetujui maka akan lanjut ke proses mengubah nilai pengajuan dan keterangan pengajuan. 


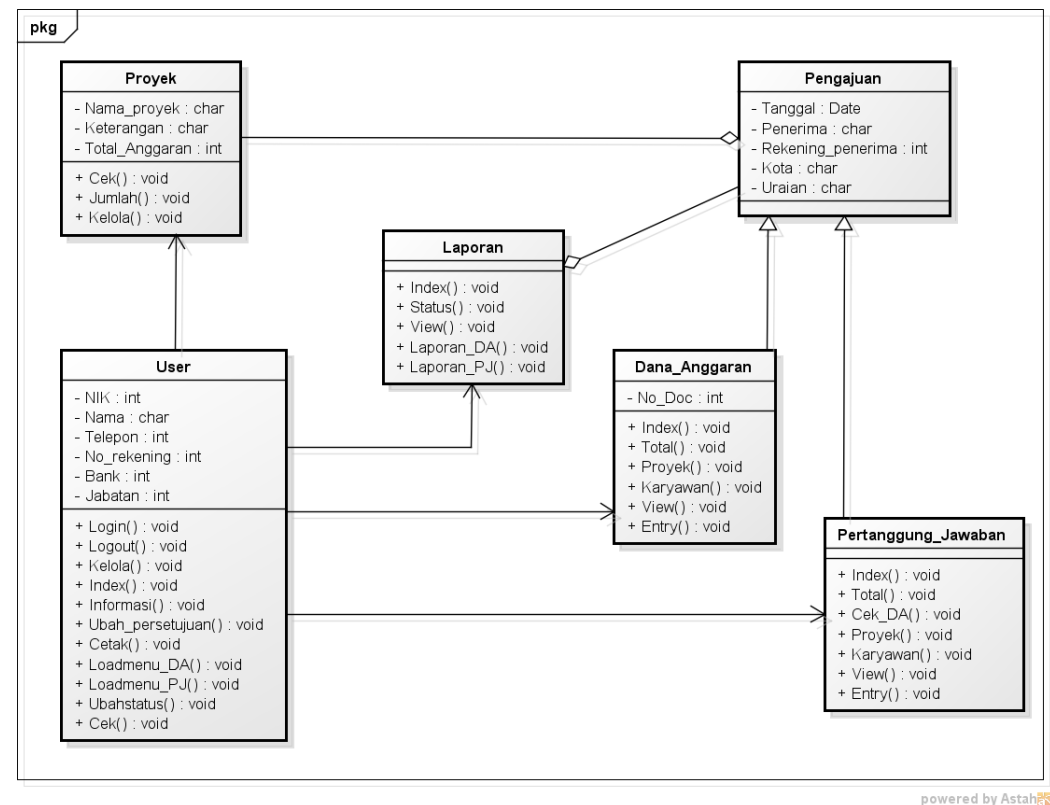

Gambar 8. Class Diagram

Pada Gambar 8 merupakan class diagram yang menunjukkan bahwa kelas user memiliki relasi dengan kelas proyek, kelas laporan, kelas dana_anggaran, dan kelas pertanggungjawaban. Kelas dana_anggaran dan kelas pertanggungjawaban merupakan anak kelas dari kelas pengajuan. Sedangkan kelas pengajuan memiliki relasi agregasi dengan kelas proyek dan kelas laporan.

Pada penilitan dengan penerapan pemodelan UML ini dihasilkan sistem Pengajuan Dana Anggaran dan Pertanggungjawaban. Sistem ini terdiri dari beberapa menu halaman meliputi login, Dana Anggaran, Riwayat Anggaran, Pertanggungjawaban Dana, Profil. Pada menu login, terdapat halaman user antara lain user tim operasional, user admin dan user kepala keuangan.

\subsection{Implementasi Halaman User Tim Operasional}

Pengujian aplikasi yang telah diimplementasikan untuk pengajuan dana anggaran pada user tim operasional terdapat beberapa menu. Pada user tim operasional bertugas untuk pengajuan awal dana anggaran proyek yang dilakukan. Tiap user memiliki hak akses masingmasing tergantung kebutuhannya. Contoh login pada user tim operasional pada Gambar 9.

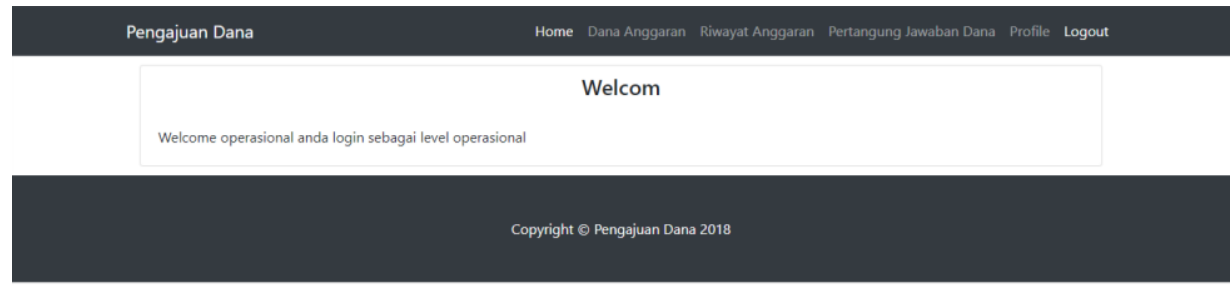

Gambar 9. Halaman Tim Operasional Setelah Login 
Pada menu yang merupakan hak akses tim operasional terdapat menu pengajuan anggaran, dimana menu ini digunakan untuk pengajuan anggaran proyek yang diperoleh. Pengajuan dana anggaran yang dilakukan kemudian akan diajukan ke kepala keuangan untuk mendapatkan persetujuan agar dana proyek bisa dicairkan untuk keperluan pelaksanaan proyek oleh tim operasional. Contoh riwayat anggaran pengajuan dana oleh tim operasional ditunjukkan pada Gambar 10.

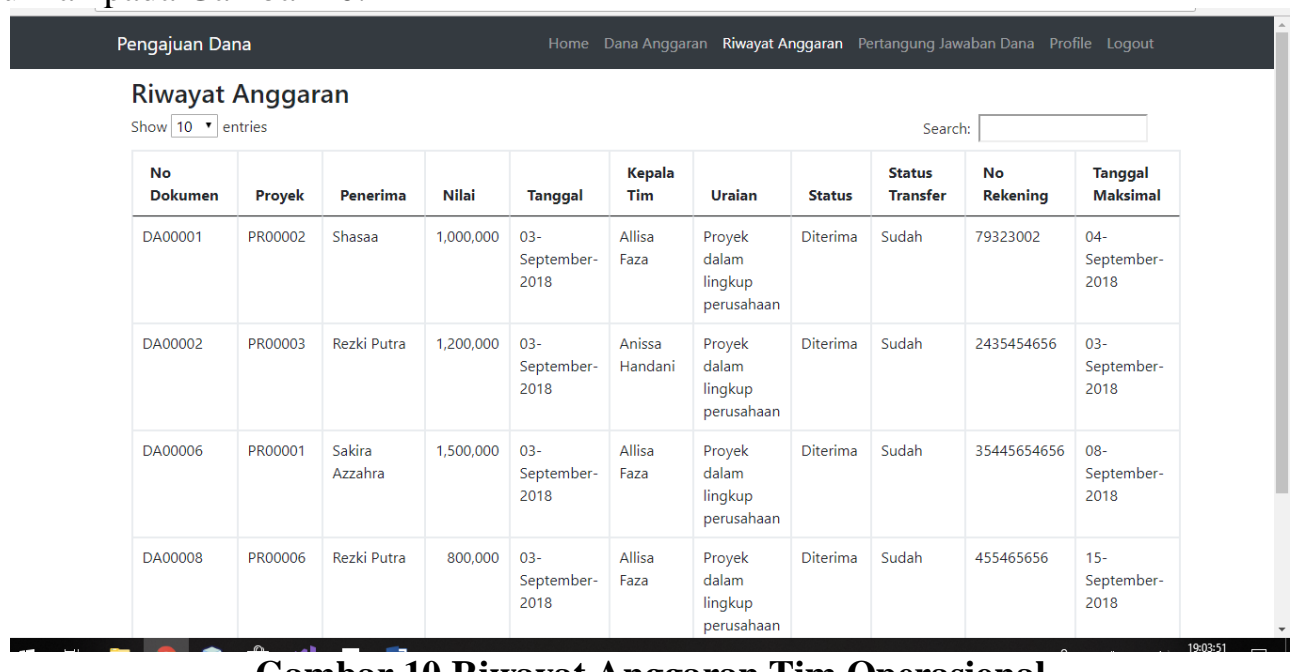

\section{Gambar 10 Riwayat Anggaran Tim Operasional}

\subsection{Implementasi Halaman User Kepala Keuangan}

Halaman awal pada menu user kepala keuangan yang akan muncul setelah Kepala Keuangan melakukan login, dimana didalam nya terdapat menu Home, Proses Anggaran, Riwayat Anggaran. Kepala keungan melakukan persetujuan terhadapa pengajuan dana anggaran yang telah diajukan oleh tim operasional.

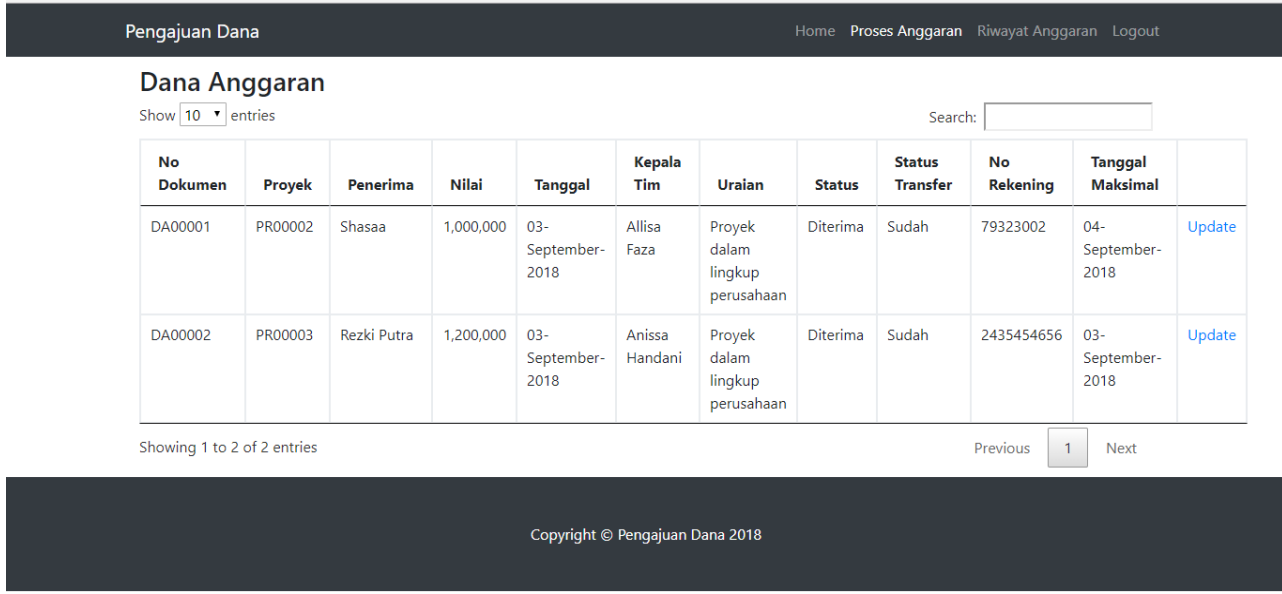

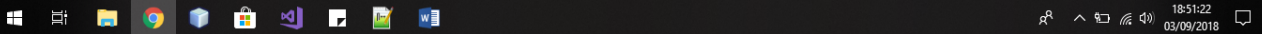

Gambar 11. Tampilan Proses Anggaran Pada User Kepala Keuangan

Halaman pada Gambar 11 adalah tampilan Proses Anggaran. Dimana didalam nya menampilkan tampilan tabel No Dokumen, Proyek, Penerima, Nilai, Tanggal, Kepala Tim, Uraian, Status, Status Transfer, No Rekening, dan Tanggal Maksimal. Juga terdapat tambahan update dalam tabel yang memiliki fungsi untuk mengubah status. Data yang ditampilkan merupakan contoh pengajuan dana yang diajukan tim operasional. 
Jika sebuah proyek sudah dilakukan dan pengajuan dana pengajuan dana sudah disetujui maka pengajuan dana akan dilanjutkan untuk proses penyelesaian proyek dan kemudian pengajuan berubah pada riwayat anggaran pengajuan. Data riwayat anggaran yang telah disetujui tidak dapat diubah kembali. Contoh riwayat anggaran yang telah disetujui seperti ditunjukkan pada Gambar 12.

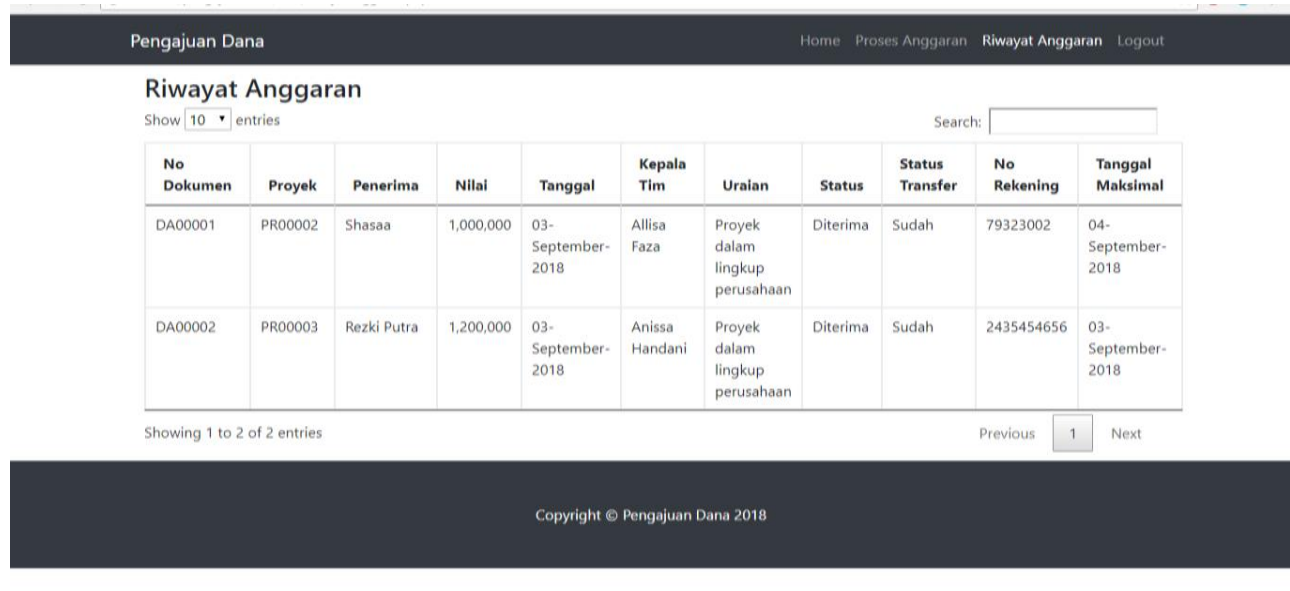

* 벼

Gambar 12 Tampilan Riwayat Anggaran Pada User Kepala Keuangan

\subsection{Implementasi Halaman User Admin}

Halaman admin adalah tampilan awal yang akan muncul setelah Admin melakukan login. Dimana didalam nya terdapat menu Home, Karyawan, Customer, Proyek, Anggaran, Riwayat Anggaran, Profile. User Admin merupakan User yang memiliki semua akses pada aplikasi pengajuan dana anggaran. Halaman login Admin ditunjukkan pada Gambar 13.

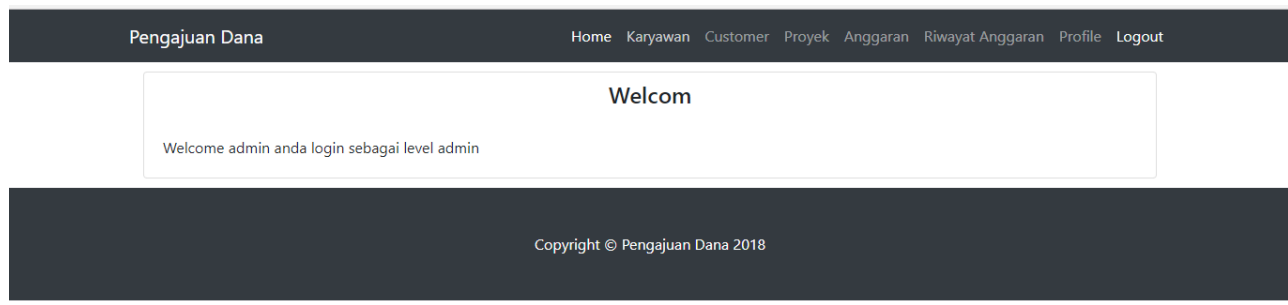

\section{Gambar 13. Tampilan Utama User Admin}

Gambar 14 merupakan halaman yang menampilkan data customer perusahaan. Pada halaman ini juga terdapat tambahan update dan delete dalam tabel yang memiliki fungsi untuk mengubah data customer dan menghapus data customer yang sudah tidak dibutuhkan. Selain itu terdapat menu Show yang menunjukkan jumlah banyaknya data dalam tabel dan menu Search untuk mencari nama yang diinginkan. 


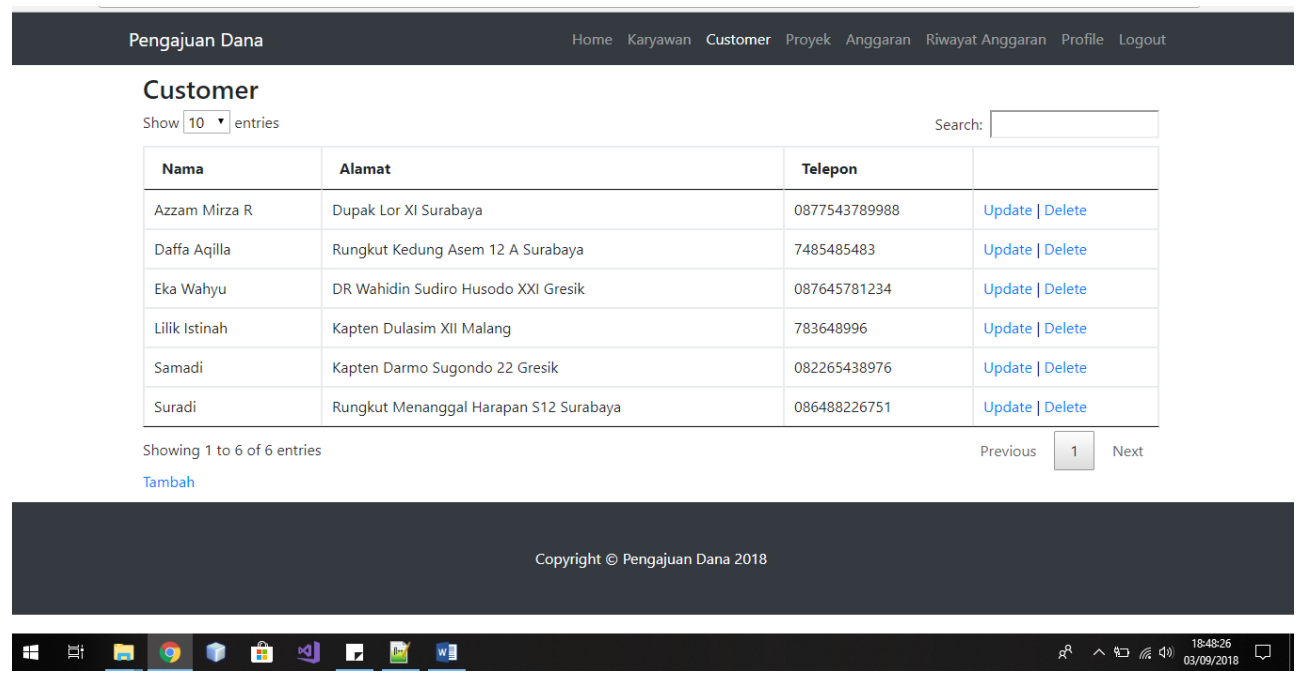

Gambar 14. Tampilan Customer Pada Admin

Pada user admin juga terdapat menu Proyek yang mengatur dan mengurusi data proyek dari perusahaan. Admin perusahaan bertugas mendata proyek yang dikerjakan oleh perusahaan kemudian menugaskan kepada tim operasional untuk melaksanakan proyek tersebut. Contoh data proyek yang dikerjakan oleh perusahaan ditunjukkan pada Gambar 15.

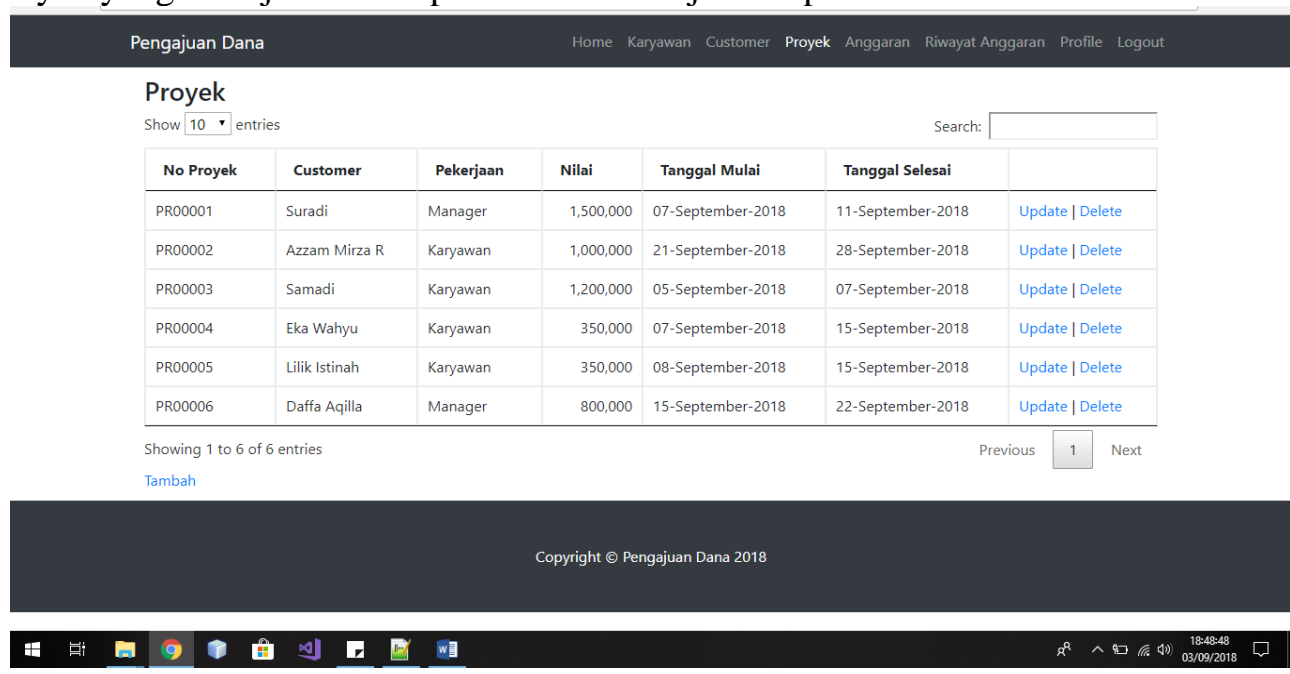

Gambar 15. Tampilan Proyek yang Dikerjakan

User admin juga bertugas melihat dan memonitoring besaran anggaran awal yang diajukan dalam pelaksanaan proyek. Gambar 16 merupakan tampilan dana anggaran pada user admin, 


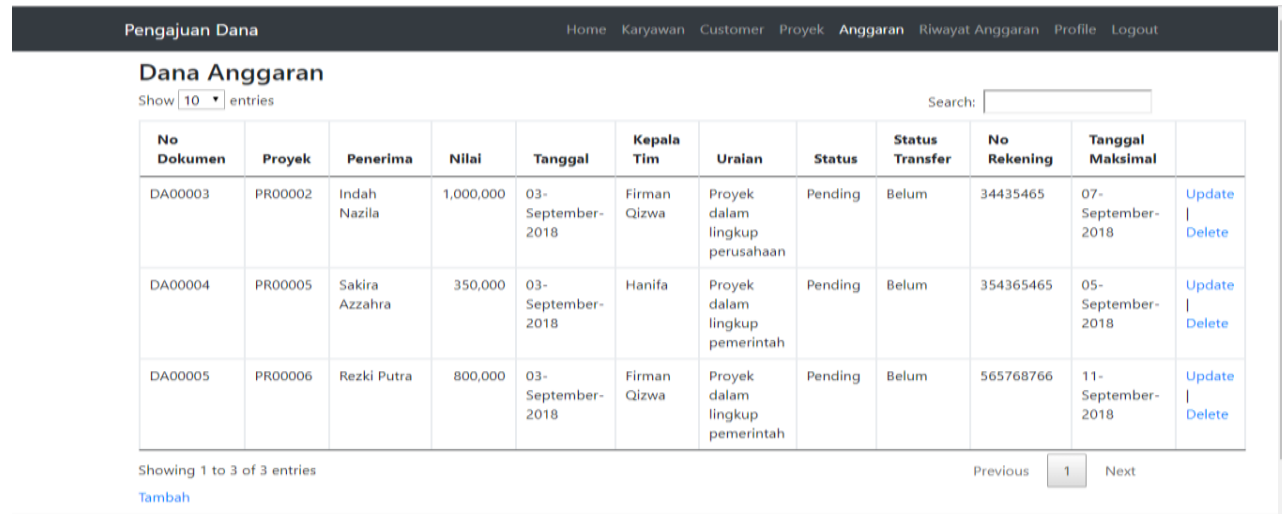

Gambar 16. Tampilan Dana Anggaran Pada User Admin

\section{Kesimpulan}

Pada penelitian dengan penerapan pemodelan UML dihasilkan sistem pengajuan dana anggaran yang dapat meningkatkan proses produktivitas perusahaan. Para karyawan CV DMK lebih mudah dalam proses pengajuan dana anggaran dan pertanggungjawaban dana proyek. Sistem yang dibuat dapat memberikan informasi mengenai pengajuan dana yang diterima atau ditolak suatu proyek, sehingga dapat membuat pekerjaan yang dikerjakan lebih efisien dan dapat mengurangi resiko kesalahan terhadap pengajuan dana proyek.

\section{Daftar Pustaka}

[1] I. Hudiarto and D. Ervien, "Penggunaan Metode New Information Economics Untuk Meningkatkan Kinerja Usaha Melalui Sistem Informasi," CommIT (Communication and Information Technology) Journal, vol. 2, no. 2, pp. 87-94, Oct. 2008.

[2] W. Brian, "UML for systems engineering," Computer Standards \& Interfaces, vol. 29, no. 1, pp. 69-81, 2007.

[3] E. Song, S. Yin, and I. Ray, "Using UML to model relational database operations," Computer Standards \& Interfaces, vol. 29, no. 3, pp. 343-354, Mar. 2007.

[4] X. Fan, "Chapter 7 - Architecture Modeling in UML," in Real-Time Embedded Systems, X. Fan, Ed. Oxford: Newnes, 2015, pp. 185-201.

[5] C. M. Keet and P. R. Fillottrani, "An ontology-driven unifying metamodel of UML Class Diagrams, EER, and ORM2," Data \& Knowledge Engineering, vol. 98, pp. 3053, Jul. 2015.

[6] H. Setiawan and M. Q. Khairuzzaman, "Perancangan Sistem Informasi Manajemen Proyek: Sistem Informasi Kontraktor,” Jurnal Khatulistiwa Informatika, vol. 5, no. 2, Dec. 2017.

[7] G. P. Arianie and N. B. Puspitasari, "Perencanaan Manajemen Proyek Dalam Meningkatkan Efisiensi Dan Efektifitas Sumber Daya Perusahaan,"J@ti Undip: Jurnal Teknik Industri, vol. 12, no. 3, pp. 189-196, Sep. 2017.

[8] T. A. Kurniawan, "Pemodelan Use Case (UML): Evaluasi Terhadap beberapa Kesalahan dalam Praktik," Jurnal Teknologi Informasi dan Ilmu Komputer, vol. 5, no. 1, pp. 77-86, Mar. 2018.

[9] M. Grobelny, I. Grobelna, and M. Adamski, "Hardware Behavioural Modelling, Verification and Synthesis with UML 2.x Activity Diagrams," IFAC Proceedings Volumes, vol. 45, no. 7, pp. 134-139, Jan. 2012.

[10] I. K. Raharjana and A. Justitia, "Pembuatan Model Sequence Diagram Dengan Reverse Engineering Aplikasi Basis Data Pada Smartphone Untuk Menjaga Konsistensi Desain Perangkat Lunak," JUTI: Jurnal Ilmiah Teknologi Informasi, vol. 13, no. 2, pp. 133142, Jul. 2015. 